\title{
Siket Zsuzsanna': IQ versus befolyásolás avagy az intelligencia hányados és a befolyásolhatóság közötti összefüggések
}

Debreceni Jogi Mühely, 2012. évi (IX. évfolyam) 2. szám (2012. április) 39-46.

A büntetőeljárásban kiemelt jelentőséggel bírnak a vádlottak, illetve a tanúk vallomásai. A vallomások alapja pedig nem más, mint az észlelés. Álláspontom szerint az észlelés sajátosságai legalább annyira egyediek és eltérőek, mint az ujjlenyomat. Az észlelés nem más, mint a személyiség lenyomata a külvilág történéseinek megítélésében. Az észlelés milyenségére és minőségére számos tényező hat. Ezen tényezők egyike az intelligencia hányados. A tudósok többsége egyetért abban, hogy az intelligencia hányados egy nagyon általános mentális képesség, amely többek között magában foglalja az érvelés, a tervezés, a problémamegoldás, az elvont gondolkodás, a komplex ideák megértése, a gyors tanulás és a tapasztalati tanulás képességeit. ${ }^{2}$ Amint az elöbbi meghatározásban is benne rejlik, az intelligencia foka egy adottság, képesség. Ebből következően az intelligencia szintje tanulással valamelyest fejleszthető, vagy a környezeti hatások miatt akár csökkenthető is, de alapjaiban nem változik, ezért inkább objektív tényező. Az intelligencia az események megértésére is hatással van, ezért a vallomásokat is képes befolyásolni. E tanulmány célja az intelligencia hányados és a befolyásolhatóság közötti összefüggések bemutatása.

\section{Az intelligencia hányados ,rejtélye”}

Az intelligencia vizsgálata során, az idő előrehaladtával különböző álláspontok ${ }^{3}$ alakultak ki arra vonatkozóan, hogy valójában milyen képességeket takar ez a kifejezés.

Sir Francis Galton elképzelése szerint az intelligencia kivételes érzelmi és észlelési készségek együttese, amelyek egyik generációról a másikra öröklődnek. Véleménye szerint minél érzékenyebb és pontosabb a személy érzékelő rendszere, annál intelligensebb.

Alfred Binet ezzel ellentétben úgy gondolta, hogy az intelligencia hányados megállapítása során nem az érzékelési és észlelési készségekre kell helyezni a hangsúlyt, hanem gondolkodási és probléma megoldási képességekre.

Binet álláspontját továbbfejlesztve Lewis Terman, a Stanford egyetem munkatársa megalkotta az intelligencia hányados mérésének mai napig használatos zsinórmértékét a Stanford-Binetintelligenciaskálát. Ennek alapján az intelligencia hányados (IQ) értéke az alábbi képlet alapján számítható ki:

\section{$\mathrm{IQ}=(\mathrm{MK} / \mathrm{ÉK}) \mathrm{X} 100$}

Az MK az egyén mentális korát jelöli, amely nem (minden esetben) egyezik meg tényleges életkorával, amelyet a képletben ÉK-val jelölnek. A mentális kor azt jelenti, hogy az ember szellemi teljesítménye alapján mennyi idősnek felel meg.

A kapott eredmény alapján felállítható egy intelligencia skála a következő értékek szerint:

25 alatt: nagyon súlyosan fogyatékos

25-40 között: súlyosan fogyatékos

40-55 között: közepesen fogyatékos

55-70 között: enyhén fogyatékos

70-90 között: alacsony intelligencia

90-110 között: átlagos intelligencia

110-120 között: magas intelligencia

120-130 között: nagyon magas intelligencia 
Ha ezen értékek gyakoriságát egy diagrammon vizsgálnánk, akkor egy harang alakú görbét kapnánk, amelynek csúcsán a 90 és 110 közötti értékek mutatnák a legnagyobb előfordulási arányt és ehhez viszonyítva minél alacsonyabb, illetve minél magasabb az intelligencia hányados, előfordulása a társadalomban annál ritkább.

A mérés eredményeként kapott értéket azonban fenntartásokkal kell kezelni, mert az IQ tesztek csak a gondolkodási képességet mérik, arra az intelligenciára vonatkozóan, amely az emberek megértéséhez vagy a másokkal való összeférhetőséghez szükséges, nem adnak tájékoztatást. $^{4}$

Másrészt az intelligencia nem különíthető el az egyén kultúrájától és megélt tapasztalataitól. ${ }^{5}$ Az előbbi kérdéskört illetően a kutatók véleménye sem egybehangzó. ${ }^{6}$ A kezdeti álláspont az volt, hogy az intelligenciát alapvetően az öröklés határozza meg. Később azonban egyes szerzők azt állították, hogy mind az öröklés mind a környezet befolyást gyakorol az intelligenciára. De ezen tábor hívei sincsenek egységes állásponton, mivel vita tárgyát képezi az öröklés és a környezet befolyásoló erejének százalékos megoszlása. Ugyanakkor egyetértés mutatkozik abban, hogy az ember életének első négy-öt évében a szociális és kulturális környezet kellöképpen serkenti, vagy csökkenti az intelligencia normális fejlődését. A kutatások kimutatták ugyanis, hogy az ingerszegény környezet rossz hatással van intelligencia hányados alakulására. Goldfarb vizsgálatai rámutattak arra, hogy az árvaházban nevelkedett gyermekek intelligencia hányadosa 23 ponttal alacsonyabb a nevelőszülöknél felserdült társaikhoz képest.

Az intelligencia fogalomkörének tisztázása után érdemes rátérni annak vizsgálatára, hogy milyen összefüggések figyelhetök meg az intelligencia hányados és a befolyásolhatóság vonatkozásában.

\section{IQ versus befolyásolás - avagy melyik az erősebb?}

Amint a gyakran emlegetett mondás tartja: a tudás hatalom. Ezzel szemben „a befolyásolás hatalom" kifejezést még nem hallottam emlegetni. Talán éppen azért, mert a befolyásolás lassabban ható és kevésbé feltünő, ezért hajlamosak vagyunk elsiklani ereje és jelentősége felett. Véleményem szerint a tudás és a befolyásolás egyenrangúak. A jelen témakörre vetítve ez azt jelenti, hogy a befolyásolás hatalmát a kihallgatást végző hatóság testesíti meg. Velük szemben áll a kihallgatott személy, legyen szó akár tanúról, akár vádlottról, aki ha kellően éles eszü, felismeri a befolyásolás eszközeit és elkerüli ennek buktatóit. Mi történik, ha ezeket mégsem ismeri fel? A taktikai csapdák áldozatává válik, akit beszippant a büntetőeljárás gépezete.

Álláspontom szerint minél alacsonyabb egy adott egyén intelligencia hányadosa, annál befolyásolhatóbb, ugyanakkor minél magasabb intelligenciával bír, annál könnyebben észreveszi a hatóságok befolyásoló törekvéseit és képes kikerülni ezeket, sőt adott esetben akár ő maga is befolyásolja környezetét.

A büncselekmények elkövetőinek intelligencia hányadosa széles palettán mozog, az igen alacsonytól az átlagoson át a kiemelkedőig. Azonban az IQ értékek eloszlását illetően némi eltérés figyelhető meg a korábban említett harang alakú görbétől. Amíg a társadalom egészére vetítve az intellektuális korlátozottság aránya 2 és $5 \%$ között mozog, addig a bünelkövetők körében a Parton-Day-White szerzőtriász szerint, ${ }^{7}$ ez az arány 0 és $25 \%$ közötti. Ennek magyarázatára számos teória született. 
Egyrészt az alacsony intelligenciával rendelkező személyek gyermekkorukban rosszabbul szerepelnek az iskolában és a további életben is. ${ }^{8}$ A gyermekkori rossz élmények hatása később újabb kudarcokhoz vezethet, amelyek a személyiség fejlődését is befolyásolják.

Egyes pszichológusok és szociológusok úgy vélik, hogy az alacsony intelligencia összefüggést mutat olyan egyéni tényezőkkel, mint a pszichológiai rendellenességek és a gyenge szociális képességek, és olyan szociális tényezőkkel, mint a munkanélküliség vagy a tanulatlanság. ${ }^{9}$

A „Susceptibility-hipotézis” szerint, az alacsonyabb intelligencia-hányados következménye a felelőtlenség és a tapasztalatokból történő tanulás képességének hiánya, és ezen okok hajlamosítják az embereket a bűnözői viselkedésre. ${ }^{10}$

A „különböző bánásmód hipotézis” szerint az alacsony intellektusú emberek az igazságszolgáltatási folyamatokkal szemben sérülékenyebbek és ennek következtében igazságtalan elbánásban részesülnek. ${ }^{11}$

Véleményem szerint az előbbi okfejtések kiegészíthetők még azzal is, hogy maga az a tény, hogy az intelligencia szint mérhetö, meghatározó élmény lehet mindenki életében. Egy IQteszt eredménye, amennyiben az egyén számára kedvező, önbizalmat ad, aminek következtében még sikeresebb emberré válhat. Ugyanakkor, ha egy ilyen teszt rossz eredménnyel zárul, az rontja az adott ember önértékelését, és torz képet alkothat magáról, amely később számos negatív töltetü cselekedet forrásává válhat. Sokan ugyanis elfelejtkeznek arról, hogy az IQ nem egy abszolút mérőszám, amely az ember minden képességét számszerüsíteni tudja, hiszen csak a gondolkodási képességeket méri, ${ }^{12}$ és az érzelmi intelligencia hányadost például nem.

\section{Az alacsony intelligencia problematikája a büntetőeljárás szakaszaiban}

A büntetőeljárás főbb szakaszai közül részletesebben a nyomozati és a tárgyalási szakaszról lesz szó, mivel a vallomástétel szempontjából ezen periódusoknak van jelentősége. A teljesség kedvéért a büntetés-végrehajtás szakasza sem hiányozhat, azonban ennek a befolyásolás szemszögéböl jóval kevesebb relevanciája van.

Az intelligencia hányadoson kívül számos egyéb tényező is hatással lehet arra, hogy milyen vallomást tesznek a vádlottak akár a nyomozati, akár a tárgyalási szakaszban. A következő megállapítások kizárólag az intelligencia kontextusában érvényesek.

\section{A nyomozati szakasz}

A büntetőeljárás kezdetén a nyomozati szakaszban, véleményem szerint a legnagyobb problémát a vallomástétel előtti figyelmeztetések jelentik. A jogi terminológia elsősorban jogban jártas emberek számára érthető, amely ismeretek elsajátítása éveket vesz igénybe. A figyelmeztetések nyelvezete nehezen értelmezhető a jog világában járatlan emberek számára, mivel szakkifejezésekkel túlzsúfolt, és megfogalmazása körülményes. Egy alacsony intelligenciával rendelkező vádlott számára már a figyelmeztetések értelmezése is „elrettentő” hatással bírhat. Ezért a kihallgatás, már a kezdetektől fogva kellemetlenné válik. A nyomozó hatóság tagjai sokszor nem fordítanak kellő időt arra, hogy elmagyarázzák, és a hétköznapi nyelvezetre fordítsák a figyelmeztetésben foglaltakat.

Az alacsony intelligenciával rendelkező vádlottak többnyire titkolják ezen hiányosságukat, mivel tisztában vannak ennek megbélyegző hatásával. Az alacsony intelligencia a legszélsőségesebb eseteket kivéve, fizikai jelekben nem nyilvánul meg, ezért a kihallatást végző nem ismeri fel, milyen nehézségei lehetnek a vádlottnak. ${ }^{13}$ Mindezek miatt a 
vádlott számára a kihallgatás kellemetlen szituációvá válik, amelyből megpróbál szabadulni. ${ }^{14}$ Az ő esetükben a kellemetlenné váláshoz nem kell a hatóságnak a legdurvább kihallgatási taktikákat alkalmaznia (pl.: ordítozás a gyanúsítottal, a terhelt barátságtalan módon való kezelése $^{15}$ ), a hatás eléréséhez enyhébb módszerek is elegendőek (pl.: a terhelt összezavarása, tagadásba vetett hit aláaknázása ${ }^{16}$ ). Ennek magyarázata az, hogy az alacsony intelligenciával rendelkezők problémamegoldó képessége általában hiányosságokkal rendelkezik, ezért a legkézenfekvőbbnek a menekülést tartják.

A menekülés a kihallgatás helyzetére vetítve nem más, mint a beismerés. Ezen vádlottak nehezen ismerik fel (akár ártatlanságuk ellenére is) a beismert büncselekmény súlyát és jelentőségét. A beismerés oka lehet még az előbbieken kívül, hogy az alacsonyabb intelligenciával rendelkező vádlottak szeretnének megfelelni a hatóság elvárásainak. ${ }^{17}$

Azon vádlottak, akiknek magasabb az intelligencia hányadosa, sokkal több megoldást képesek kitalálni a kihallgatások során. A beismerés náluk ritkább, mivel más alternatívákat is el tudnak képzelni a vallomástétel során, másrészt jobban megértik a törvény által biztosított jogaikat, és jobban képesek élni ezen jogaik adta lehetőségekkel.

Amint arról korábban szó esett, megfigyelhető, hogy a nyomozó hatóság tagjai nem fordítanak kellő figyelmet arra, hogy a vádlottak személyes tulajdonságait is górcső alá vegyék, és ebböl következtessenek a vádlott intelligencia hányadosára. Ennek a büntethetőség szempontjából különös jelentősége lenne, mert a kóros elmeállapot a Btk. 24. § (1) bekezdése szerint büntethetőséget kizáró ok, amennyiben ez az állapot az elkövetőt képtelenné teszi arra, hogy cselekményének következményeit felismerje, vagy ezen felismerésnek megfelelően cselekedjék. A Btk. 24. § (2) bekezdése szerint, ha az elmemüködés valamely kóros állapota az elkövetőt korlátozza a cselekmény következményeinek felismerésében vagy abban, hogy ezen felismerésnek megfelelően cselekedjék, akkor a büntetés korlátlanul enyhíthető. Az elmemüködés kóros állapotának egyik változata a gyengeelméjüség. A gyengeelméjüség olyan született, illetőleg a magzati vagy kora gyermekkori károsodás következtében kialakult értelmi fogyatékosság, amely orvosi úton még átmenetileg sem befolyásolható. A mentális retardációnak három fokozata különíthető el, ezek súlyossági sorrendben a debilitás, az imbecilitás és az oligofrénia. ${ }^{18} \mathrm{~A}$ fogyatékosság egyik jele lehet az intelligencia teszten elért alacsony eredmény. Az intelligencia skálán a 70 alatti eredményt elérők esetében már szó lehet enyhe fogyatékosságról, 40-55 között közepes, 40-25 között súlyos, míg 25 alatti IQ estén nagyon súlyos fogyatékosságról beszélhetünk. A gyengeelméjüség az előbbiek függvényében lehet büntethetőséget kizáró ok vagy a korlátlan enyhítésre lehetőséget adó körülmény. Ezzel éppen azok a vádlottak vannak tisztában, akik magasabb intelligenciával rendelkezvén megpróbálják a szakértő előtt „eljátszani”, hogy intelligencia szintjük a fogyatékosság határait feszegei. Ugyanakkor azon elkövetők, akik valóban ilyen hiányosságokkal küzdenek, inkább titkolják a problémájukat, mert szégyellik, pedig a beszámítási képesség korlátozottsága általában enyhítő körülmény akkor is, ha a Btk. 24. § (2) bekezdésének alkalmazására nincs alap. ${ }^{19}$

\section{A tárgyalási szakasz}

A tárgyalási szakaszban az alacsony intelligenciával rendelkező vádlottak szintén nehézségekbe ütköznek. Ezért annak ténye, hogy az eljárás ezen szakaszában szintén sor kerülhet a kihallgatásukra, számukra nem feltétlenül kedvező. Még akkor sem, ha bíróság a nyomozó hatósággal ellentétben nem a vádló, hanem a pártatlan ítész szemüvegén keresztül nézi őket. 
Ennek egyik oka a tárgyalás nyelvezete, amely a nyomozati szakaszhoz hasonlóan számukra szintén bonyolult és nehezen értelmezhető. Ezért hiába hangzanak el itt is a figyelmeztetések, ezeket a vádlottak sokszor nem értik meg, vagy a magyarázatok hatására csak úgy tesznek, mintha megértenék, de valójában ez nem igaz.

A tárgyalások kevés kivételtől eltekintve nyilvánosak. Ennek az alacsony intelligencia szempontjából azért van jelentősége, mert ezen vádlottakra már a nyomozati szakban történő kihallgatás is rossz hatással volt. Amint arról korábban szó esett az alacsony intelligenciával bíró vádlottak szégyellik ezen hiányosságukat, és igyekeznek ezt titkolni. A titkolózás annál súlyosabb teherként nehezedik az egyénre, minél több másik ember előtt kell leplezni azon tulajdonságát, amelyet szégyell. A tárgyalás folyamata minden vádlott számára stresszel jár, de az elöbbi okok miatt ezen vádlottak még nehezebb helyzetben vannak, nagyobb lelki nyomás nehezedik rájuk.

Véleményem szerint ezek a körülmények hatással vannak a tárgyalás során tett vallomásukra is, amelyek következményeképp a tárgyaláson tett vallomással a második esély jobbító lehetősége helyett, inkább csak rontanak helyzetükön és megítélésükön. Megítélésükön azért rontanak, mert a fokozott stressz és a problémamegoldó képesség hiánya miatt kétségbeesésükben olyan viselkedési módokat választanak a tárgyalás során, amely a jelenlévőkben rosszallást, megbotránkozást kelt.

A befolyásolás nem egyirányú, hanem oda-vissza ható folyamat. Amint a tárgyaláson elhangzottak hatással vannak a vádlott viselkedésére, úgy a vádlott viselkedése is hatással van a bíróra, illetve az ügyészre. Álláspontom szerint a tárgyalóteremben tanúsított magatartás akár az ítéletet is befolyásolhatja, legalább a büntetés mértékének tekintetében.

Ezért a tárgyalás szakaszában különösen fontosnak tartom a védő szerepét, akinek aktív közremüködésével mindent meg kell tennie annak érdekében, hogy védencének a szükséges felvilágosítást megadja, és érthetőbbé tegye számára a tárgyaláson használt bonyolultnak tünő jogi formulákat. A kutatások alapján megfigyelhetö, hogy az alacsony intelligenciával rendelkező vádlottakat gyakrabban védik kirendelt ügyvédek. ${ }^{20}$ Ennek oka véleményem szerint az, hogy ezen vádlottak anyagi lehetőségei általában korlátozottabbak.

A tárgyalási szakasz záró akkordja nem más, mint az ítélet meghozatala. Az alacsony intelligencia hányadosú vádlottak esetében megfigyelhető, hogy nagyobb valószínüséggel részesülnek szabadságvesztés büntetésben. Ennek egyik oka az elkövetett büncselekmény típusa vagy a tárgyaláson tanúsított magatartásuk. ${ }^{21}$

Ezen vádlottak sokkal ritkábban részesülnek pénzbüntetésben, és hosszabb ítéleteket töltenek le, mint a hasonló büncselekményt elkövető, de magasabb intelligenciával rendelkező elítéltek. $^{22}$ A pénzbüntetés ritka előfordulását feltételezésem szerint az magyarázza, hogy ezen vádlottak jövedelmi-vagyoni viszonyai általában arra engednek következtetni, hogy a pénzbüntetést úgysem lennének képesek kifizetni. Másrészt a tárgyaláson tanúsított magatartásuk, a konfliktuskezelés képességének hiánya, azt a benyomást keltheti a bíróban, hogy az ő esetükben a pénzbüntetés nem rendelkezik kellő visszatartó erővel.

\section{A büntetés-végrehajtás szakasza}

Ebben a szakaszban az alacsony intelligenciájú elítéltekkel összefüggésben a kutatások arra az eredményre jutottak, hogy a büntetésük nagyobb részét töltik le, mielőtt feltételesen szabadlábra helyeznék őket. ${ }^{23}$ Ez azzal magyarázható, hogy a feltételes szabadlábra helyezés egyik kritériuma a jó magaviselet. Olyan emberek számára, akik természetükből adódóan 
nehezebben kezelik a konfliktusokat sokkal nagyobb próbatétel egy ilyen elvárásnak megfelelni.

\section{Konklúzió}

Végső következtetésként megállapítható, hogy az alacsony intelligenciával rendelkező vádlottak a büntetőeljárás minden szakaszában számos nehézségbe ütköznek, mivel az eljárás folyamatainak, nyelvezetének megértése sokkal nagyobb terhet jelent számukra, mint a többi vádlottnak. Másrészt az alacsony intelligencia következményeként előtérbe kerülö jellemvonások, mint a problémamegoldó készség csekély foka, a kifejezési, megértési és alkalmazkodási problémák ahhoz vezethetnek, hogy megítélésük a nyomozó hatóság és későbbiekben a bíróság részéröl kedvezötlenebb, mint amilyen az általuk elkövetett büncselekmény súlya. Ez a kedvezötlen megítélés végső soron az ítéletekben is megmutatkozik. Így ezen vádlotti csoport esetében különös gondot kell fordítani arra, hogy megértsék a körülöttük zajló jogi folyamatokat, és éljenek a törvény által felkínált lehetőségekkel. Ennek biztosítása elsősorban a védők feladata. Ugyanakkor a nyomozó hatóságnak, az ügyészségnek és a bíróságnak minél alaposabb emberismeretre kell törekednie, hogy a vádlott adott helyzetben tanúsított magatartását megfelelően tudják értékelni. Sok hasonló tettnek más és más mozgatórugói lehetnek. A vádlott hangos szava irányulhat feltünéskeltésre, a feszültség levezetésére, de az is lehet, hogy valójában nem más, mint egy utolsó kétségbeesett segélykiáltás a meg nem értettség nyelvén.

\section{IQ versus impressionability - Summary}

This is an essay about the connection of impressionability and intelligence quotient. The intelligence quotient of witness or accused has main role in the criminal procedure.

So, what are the intelligence and the intelligence quotient? The intelligence is a mental power, that contains the quality of argumentation, contemplation, learning, problem solution and the abstract thinking. This mental power helps to understand the happenings in the world. The intelligence quotient of the witness or accused is very important, because the quality of perception is based on the intelligence quotient. The perception shows how they can remember the criminal situations. The intelligence quotient depends on the social and cultural environment, the inherited qualities, and the personal experiences.

The important question is which is the stronger, the intelligence or the impressionability. High intelligence quotient is a mean of the witness or accused to escape form impressionability. On the other hand, the authorities try to use the power of influence. So two powers meet in the criminal procedure, the intelligence and the influencing, and usually the stronger is the winner.

The intelligence quotient has main role in the part of the investigation and the trial. The warnings before the interrogation are written in the difficult language of law. So it would be a problem in the part of investigation, because the witness or accused does not understand these. Because of that they would say or tell something that they would not tell in normal circumstances. The low intelligence makes the accused confess their real or believed sin. The accused with higher intelligence quotient understands much better the warning, and they can use those possibilities the law permits them. Their combinative quality is higher, so they discover another solutions not just the confessing. The authorities shall pay attention to the intelligence quotient of the accused, because the extremely low intelligence quotient would be 
the sign of mental retardation. The mental retardation is a kind of pathological mental state. The accused who suffers in pathological mental state is not being punishable or his or her punishment may be reduced unlimited.

The language of trials is also difficult and the other problem with it is publicity. The accused with low IQ feels shame because of their low IQ so they want to keep it secret. The accused becomes stressed in the trial so they lose their second chance to make things better, because they are not able to confess without impressions again. Low intelligence quotient usually cooperates with low ability of problem solution, so the accused with low intelligence can't adapt themselves to the occasion of the trial. This circumstance would influence the judges, when they impose punishment, so the punishment would be stricter.

The conclusion is that the accused with low intelligence quotient meets with some difficulties during the criminal procedure, so the consuels for the defence shall pay attention to them, and help their clients with comments of the legal texts. On the other hand, the authorities shall be out for the good knowledge of mankind.

\section{Felhasznált irodalom}

- Bócz Endre : A gyanúsított kihallgatásának amerikai taktikájáról. Belügyi Szemle, 2001. 2236 o.

- Donald O. Hebb : A pszichológia alapkérdései, Gondolat-Trivium, Budapest, 1994. 186.189. o.

- Felicity Parton - Andrew Day - Jack White: Empikus tanulmány az intellektuális képességek és a jogi folyamatok megértése közötti kapcsolatról vizsgálati fogságban lévő férfiak esetén. Psychiatry, Psychology and Law 11.1 (april 2004): p96(14). 1-2. o.

- Nagy Ferenc : A magyar büntetőjog általános része, Korona Kiadó 2004. 238. o.

- Richard P. Conti : A hamis vallomás pszichológiája. Hitelességi értékelés és tanúpszichológiai folyóirat. 1999. 2. évfolyam elsö sz. - The Journal of Credibility Assessment and Witness Psychology 1999, Vol. 2, No. 1, -The Psychology of False Confessions 9. o.

- Rita L. Atkinson - Richard C. Atkinson - Edward E. Smith - Daryl J.Bem : Pszichológia, Osiris-Századvég, Budapest, 1995. 339.-341. o.

- Scott O. Lilienfeld - Steven Jay Lynn - John Ruscio - Barry L. Beyerstein: 50 pszichológiai tévhit, Partvonal Könyvkiadó, Budapest, 2010, 112. o

\section{Felhasznált jogszabályok}

1978. évi IV. törvény a Büntető törvénykönyvröl (Btk.)

56/2007. BK vélemény

\footnotetext{
${ }^{1}$ A szerzó

${ }^{2}$ Scott O. Lilienfeld - Steven Jay Lynn - John Ruscio - Barry L. Beyerstein: 50 pszichológiai tévhit, Partvonal Könyvkiadó, Budapest, 2010, 112. o.

${ }^{3}$ Rita L. Atkinson - Richard C. Atkinson - Edward E. Smith - Daryl J.Bem : Pszichológia, Osiris-Századvég, Budapest, 1995. 339.-341. o.

${ }^{4}$ Donald O. Hebb : A pszichológia alapkérdései, Gondolat-Trivium, Budapest, 1994. 183. o.

${ }^{5}$ Rita L. Atkinson - Richard C. Atkinson - Edward E. Smith - Daryl J.Bem : Pszichológia, Osiris-Századvég, Budapest, 1995. 339. o.

${ }^{6}$ Donald O. Hebb : A pszichológia alapkérdései, Gondolat-Trivium, Budapest, 1994. 186.-189. o.
} 
${ }^{7}$ Felicity Parton - Andrew Day - Jack White: Empikus tanulmány az intellektuális képességek és a jogi folyamatok megértése közötti kapcsolatról vizsgálati fogságban lévő férfiak esetén. Psychiatry, Psychology and Law 11.1 (april 2004): p96(14). 1. o.

${ }^{8}$ Donald O. Hebb : A pszichológia alapkérdései, Gondolat-Trivium, Budapest, 1994. 186. o.

${ }^{9}$ Felicity Parton - Andrew Day - Jack White: Empikus tanulmány az intellektuális képességek és a jogi folyamatok megértése közötti kapcsolatról vizsgálati fogságban lévő férfiak esetén. Psychiatry, Psychology and Law 11.1 (april 2004): p96(14). 1. o.

${ }^{10}$ Felicity Parton - Andrew Day - Jack White: Empikus tanulmány az intellektuális képességek és a jogi folyamatok megértése közötti kapcsolatról vizsgálati fogságban lévő férfiak esetén. Psychiatry, Psychology and Law 11.1 (april 2004): p96(14). 1. o.

${ }^{11}$ Felicity Parton - Andrew Day - Jack White: Empikus tanulmány az intellektuális képességek és a jogi folyamatok megértése közötti kapcsolatról vizsgálati fogságban lévő férfiak esetén. Psychiatry, Psychology and Law 11.1 (april 2004): p96(14). 1. o.

${ }^{12}$ Rita L. Atkinson - Richard C. Atkinson - Edward E. Smith - Daryl J.Bem : Pszichológia, Osiris-Századvég, Budapest, 1995. 340. o.

${ }^{13}$ Felicity Parton - Andrew Day - Jack White: Empikus tanulmány az intellektuális képességek és a jogi folyamatok megértése közötti kapcsolatról vizsgálati fogságban lévő férfiak esetén. Psychiatry, Psychology and Law 11.1 (april 2004): p96(14). 2. o.

${ }^{14}$ Richard P. Conti : A hamis vallomás pszichológiája. Hitelességi értékelés és tanúpszichológiai folyóirat. 1999.

2. évfolyam első sz. - The Journal of Credibility Assessment and Witness Psychology 1999, Vol. 2, No. 1, -The Psychology of False Confessions 9. o.

${ }^{15}$ Bócz Endre: A gyanúsított kihallgatásának amerikai taktikájáról. Belügyi Szemle, 2001. 22-36 o.

${ }^{16}$ Bócz Endre: A gyanúsított kihallgatásának amerikai taktikájáról. Belügyi Szemle, 2001. 22-36 o.

${ }^{17}$ Felicity Parton - Andrew Day - Jack White: Empikus tanulmány az intellektuális képességek és a jogi folyamatok megértése közötti kapcsolatról vizsgálati fogságban lévő férfiak esetén. Psychiatry, Psychology and Law 11.1 (april 2004): p96(14). 2. o.

${ }^{18}$ Nagy Ferenc: A magyar büntetöjog általános része, Korona Kiadó 2004. 238. o.

${ }^{19}$ 56/2007. BK vélemény

${ }^{20}$ Felicity Parton - Andrew Day - Jack White: Empikus tanulmány az intellektuális és a jogi folyamatok mérése közötti kapcsolatról vizsgálati fogságban lévő férfiak esetén. Psychiatry, Psychology and Law 11.1 (april 2004): p96(14). 2. o.

${ }^{21}$ Felicity Parton - Andrew Day - Jack White: Empikus tanulmány az intellektuális képességek és a jogi folyamatok megértése közötti kapcsolatról vizsgálati fogságban lévő férfiak esetén. Psychiatry, Psychology and Law 11.1 (april 2004): p96(14). 2. o.

${ }_{22}$ Felicity Parton - Andrew Day - Jack White: Empikus tanulmány az intellektuális képességek és a jogi folyamatok megértése közötti kapcsolatról vizsgálati fogságban lévő férfiak esetén. Psychiatry, Psychology and Law 11.1 (april 2004): p96(14). 2. o.

${ }^{23}$ Felicity Parton - Andrew Day - Jack White: Empikus tanulmány az intellektuális képességek és a jogi folyamatok megértése közötti kapcsolatról vizsgálati fogságban lévő férfiak esetén. Psychiatry, Psychology and Law 11.1 (april 2004): p96(14). 2. o. 